\title{
Revealing the effect of probiotic combination: Lactobacillus rhamnosus and Lactobacillus acidophilus (Lacidofil@) on acute diarrhea in adult patients
}

\author{
Marcellus Simadibrata $^{1 \star}$, Suzanna Ndraha ${ }^{2}$, Robert Tedjasaputra ${ }^{3}$, Ari Fahrial Syam ${ }^{1}$, Achmad \\ Fauzi Aan Santi ${ }^{1}$ and Aziz Rani ${ }^{1}$ \\ ${ }^{1}$ Gastroenterology Division, Department of Internal Medicine, Faculty of Medicine, University of Indonesia/Cipto \\ Mangunkusumo Hospital Jakarta, Indonesia. \\ ${ }^{2}$ Department of Internal Medicine Koja Hospital Jakarta, Indonesia. \\ ${ }^{3}$ Department of Internal Medicine, Tarakan Hospital Jakarta, Indonesia.
}

Accepted 19 November, 2012

\begin{abstract}
The concept of taking probiotic supplementation for better health and improving acute episodes of diarrhea has been well-known. Several studies have indicated that probiotic supplementation bring beneficial effects for patients with diarrhea. However, there is a striking lack of evidence on the supplementation of probiotic products in adult patients with acute diarrhea and prescribing probiotics for acute diarrhea has been underestimated. A prospective, double-blind, randomized, controlled clinical trial was conducted in adult patients who visited the study sites at three hospitals (Cipto Mangunkusumo, Koja and Tarakan Hospital) in Jakarta between 2007 and 2010. The subjects were divided into 2 groups, that is, the treatment group receiving Lactobacillus spp. product at the dose of 3 $\times 2$ capsules for 7 days and the control group receiving placebo. Statistical analysis was performed using Statistical Package for the Social Sciences (SPSS) software program. The $p$ value of $<0.05$ was considered significant. The study demonstrated a significant result of faster recovery from diarrhea $1.02 \pm 0.48$ days sooner than the placebo group $(p=0.018)$. Greater improvement on clinical outcomes (frequency of stools, stool consistency, abdominal pain, nausea, vomiting, bloating, headache, fever and tenesmus) were observed in the group receiving Lactobacillus spp. supplementation; however, the result was statistically significant on stool consistency only. Combined probiotic supplementation appears to be a promising therapeutic agent for treatment of acute diarrhea in adults. However, further controlled clinical studies as well as good storage, handling and distribution is essential to explore the therapeutic benefit for possible practical clinical application.
\end{abstract}

Key words: Lactobacillus rhamnosus, Lactobacillus acidophilus, probiotic supplementation, acute diarrhea, adults.

\section{INTRODUCTION}

As one of developing countries with poor hygiene and sanitation, Indonesia has a considerable morbidity and mortality rate for diarrheal diseases (Unicef Indonesia, 2012; World Bank-Agriculture and Rural Development, 2012; USAID Indonesia, 2012). Acute diarrhea is one of the most common diagnoses in daily clinical practice (Hendarwanto, 1996). It is often a primary sign and

\footnotetext{
*Corresponding author. E-mail: marcellus_sk@yahoo.com.
}

symptom of gastrointestinal tract disorder which may cause serious problems both in children and adults. The symptom ranges from mild and self-limiting to severe, which may become a common cause of death in developing countries. Worldwide, acute diarrhea causes over 5 million deaths per year.

In developing countries, it remains the second most common cause of death in children. It also causes a substantial problem in adult patients. With over 600 million international trips being taken annually, the traveler's diarrhea in adults would be a special problem. 
Therefore, a prompt and effective treatment to manage acute diarrhea is critical in reducing the high morbidity and mortality rate. Furthermore, there are great concerns on the use of antibiotics in managing acute diarrhea, as most of infectious diarrhea cases are viral. Inappropriate use of antibiotics will disturb the gastrointestinal flora, which may cause a longer duration of diarrhea, greater side effect and lead to the development of antibiotic resistance (Manatsathit et al., 2002; Rani, 2002; Field, 2003; Qadri et al., 2005; Oyofo et al., 2002). Thus, oral rehydration therapy, ongoing fluid replacement and nutritional support, including prescribing probiotic supplementation to promote recovery from acute diarrhea are parts of the core foundation treatment for acute diarrhea.

The concept of taking probiotic supplementation for better health and improving acute episodes of diarrhea is not new. Several studies have indicated that probiotic supplementation may normalize the gut microflora, which is an important protection of the host against gastrointestinal (Gl) tract diseases (De Roons and Katan, 2000; van Niel et al., 2002; Tiaskal et al., 1995, 2005; Reid et al., 2003; Guandalini et al., 2000; Shornikova et al., 1997; Guerrant et al., 2001).

Other studies have provided evidences that the supplementation of probiotic products containing Lactobacillus acidophilus and other Lactobacillus spp has significantly shortened the duration of diarrhea and offered faster recovery from diarrhea 1 day sooner in children and infants (Canani et al., 2007; Agustina et al., 2007; Sazawal et al., 2006; Hatta et al., 2011; Putra et al., 2007). Several clinical studies have demonstrated that probiotic combination of $L$. rhamnosus and $L$. acidophilus (Lacidofil囚) as an effective supplement for various gastrointestinal diseases in children (Foster et al., 2011). However, many probiotic supplementation studies have yielded conflicting results, and prescribing probiotics for acute diarrhea has been underestimated. Moreover, there is a striking lack of evidence on the supplementation of probiotic products in adult patients with acute diarrhea. To our knowledge, this is the first study in Indonesia that investigated the effect of combined probiotic agents on acute diarrhea in adult patients.

The aim of our study was to reveal the beneficial effect of combined probiotic product of $L$. rhamnosus and $L$. acidophilus (Lacidofil囚) on acute diarrhea in adult patients including shorter diarrhea duration, improved stool frequency and consistency, as well as improved abdominal and other symptoms compared to placebo.

\section{MATERIALS AND METHODS}

\section{Study subjects and design}

A prospective, double-blind, randomized, controlled clinical trial was conducted at three hospitals (Cipto Mangunkusumo, Koja and Tarakan Hospital) in Jakarta between 2007 and 2010. Those hospitals are public hospitals funded by Indonesian government and Cipto Mangunkusumo Hospital is the top National Referral Center Government Hospital. Subjects enrolled in our study were eligible patients who visited the three hospitals during the study period. The inclusion criteria were: (1) patients with acute diarrhea; (2) aged 13 to 60 years; and (3) did not have severe complications. Acute diarrhea was defined as the passing of three or more loose or watery stools $(>200 \mathrm{~mL} / \mathrm{h})$ within a $24 \mathrm{~h}$ period, lasting less than 14 days. Patients were excluded from study if: (1) they had a serious complication (renal failure, metabolic acidosis, severe dehydration, hypovolemic shock, heart failure, vomiting, anorexia); (2) had a history of allergy to Lactobacillus spp.; (3) had diarrhea caused by amoeba, colorectal cancer or tumor; (4) had exclusion criteria with a proven cause of diarrhea, amoeba, colorectal cancer or tumor; (5) were taking antibiotic therapy.

The subjects were divided into 2 groups. The first group of 38 patients received oral rehydration salt (Oralit $\circledast$ ) and the probiotic combination product of Lactobacillus spp. (L. rhamnosus and $L$. acidophilus) at the dose of $3 \times 2$ capsules for 7 days. Each probiotic capsule contained a combination of two strains, that is $L$. rhamnosus $R 0011\left(1.9 \times 10^{9} \mathrm{CFU}\right)$ and L. acidophilus R0052 $(0.1 \times$ $\left.10^{9} \mathrm{CFU}\right)$; while, the other group $(\mathrm{n}=37$ ) received oral rehydration salt and placebo capsule at equal dose of $3 \times 2$ capsules for 7 days. The subjects received capsules of Lactobacillus spp. or placebo for 7 days. They were also asked to contact the investigators if diarrhea recurred in follow-up period of 1 week. The treatment was administered as early as possible after the informed consent had been obtained. There was no minimal time interval in patient between the beginning of the symptoms and the administration of the Lactobacillus spp. capsules.

Clinical presentation of illness before and after treatment, including symptoms of diarrhea, abdominal complaints and other complication were recorded for all the cases. Laboratory examinations of blood and stool analysis were carried out. Blood specimens were collected for blood analysis (hemoglobin level, leukocyte count, hematocrit, platelet count, ureum and creatinine level) to exclude any complication. Stools were collected from each subject for routine stool analysis to determine whether the diarrhea was caused by infectious agents, such as bacteria, amoeba or fungi. The stool consistency and the severity of diarrheam, as well as other symptoms (abdominal pain, nausea, vomiting, bloating, tenesmus, headache and daily activity disturbance) were monitored throughout the study period and rated on a 4-point scale: no symptom (0), mild symptom (1), moderate symptom (2), and severe symptom (3). The symptoms of fever and thirst were self-reported and recorded as positive and negative results.

\section{Statistical analysis}

Data was entered in specific forms (case report forms/CRFs) of data Epi template. Statistical analysis was performed using Statistical Package for the Social Sciences (SPSS) software program to determine the statistical differences between study groups. Independent t-test was used to determine the mean value and $95 \%$ confidence interval for the duration of diarrhea. The $p$ value of $<0.05$ was considered significant.

\section{Ethical approval}

The study protocol had been approved by the Ethical Review Committee of Medical Faculty, University of Indonesia

\section{RESULTS}

A total of 90 patients ( $n=45$ for each group) were initially 
Table 1. Socio-demographic characteristics of patients receiving Lactobacillus spp. or placebo.

\begin{tabular}{lccc}
\hline Characteristics & Lactobacillus Spp (\%) $(\mathbf{n = 3 8})$ & Placebo $(\%)(\mathbf{n}=\mathbf{3 8})$ & P value \\
\hline Sex & 15 & 16 & 1.000 \\
Male & 23 & 22 & \\
Female & & & \\
& $32.74 \pm 12.65$ & $35 \pm 13.58$ & \\
Age: Mean \pm SD (years) & & & \\
Ethnicity & 18 & 18 & \\
Javanese & 6 & 5 & \\
Sundanese & 1 & 0 & \\
Aceh & 4 & 1 & \\
Batak & 2 & 2 & \\
Padang & 1 & 1 & \\
Bugis/Makassar & 1 & 0 & \\
Timor & 1 & 0 & \\
Ambon & 2 & 6 & \\
Betawi & 1 & 1 & \\
Chinese & 1 & 4 & 0.914 \\
Others & & & \\
Type of diarrhea: & 8 & 7 & 25 \\
Infectious* & 36 & & \\
Non-infectious & & & \\
\hline
\end{tabular}

*Infectious diarrhea was defined based on positive laboratory test results revealing the causative infectious agents, such as bacteria, amoeba or fungi.

enrolled in our study and included in the per-protocol analysis. However, only 76 patients $(n=38$ for each group) had completed the study, who were included in the intention-to-treat (ITT) analysis. Socio-demographic characteristics of our subjects are presented in Table 1. Both groups were similar with respect to most characteristics. Most subjects were female, Javanese and had suffered from non-infectious diarrhea.

The per-protocol analysis indicated that the duration of diarrhea in group 1 (Lactobacillus spp.) was significantly shorter than group 2 (placebo) with $p$-value of 0.018 (Table 2). The results demonstrated faster recovery from diarrhea $1.02 \pm 0.48$ days sooner than the placebo group. The recovery from diarrhea was determined by complete decline of clinical symptoms (stool consistency, number of stool and other symptoms such as stomach pain, vomiting, fever, and lack of appetite). Greater recovery of stool frequency on day 0 to 3 was also noticed in group 1 (Lactobacillus spp.) than the placebo group; however, such improvement was not statistically significant $(p>$ 0.05). Better improvement of stool consistency was observed in group 1 compared to placebo group during the study period. Although the difference was statistically significant on day $2(p=0.049)$ and day $5(p=0.048)$, but no significant differences were observed on the other days (Table 2).
In Lactobacillus spp. group, there was improvement of other clinical symptoms comparing day 0 and day 7 significantly $(p<0.001)$ (Table 3$)$. Faster improvement on some clinical outcomes were observed in group 1 (Lactobacillus spp.) than the placebo group when comparing the complaints on Day 0 and 7 . Only the stool consistency in Lactobacillus spp. group was improved faster than in placebo group significantly $(p=0.022)$ (Table 3). No serious adverse events was found both in Lactobacillus spp. group and the placebo group.

\section{DISCUSSION}

Most of our study subjects were female, Javanese and had suffered from non-infectious diarrhea. Our findings seem to be consistent with other studies which also found acute non-infectious diarrhea predominantly in women. Conversely, other studies have found inconsistent results which demonstrated that acute diarrhea is also found in men (Supcharassaeng and Suankratay, 2011; Guandalini, 2012). As one of tropical developing countries, we could expect that there would be more infectious cases found. However, in this study, we observed a majority of non-infectious acute diarrhea cases. In contrast, contradictory results were observed by 
Table 2. Clinical outcome of patients receiving Lactobacillus spp. or placebo.

\begin{tabular}{cccc}
\hline \multicolumn{1}{c}{ Parameter } & $\begin{array}{c}\text { Lactobacillus spp } \\
\text { (Lacidofil@) }\end{array}$ & Placebo & $\begin{array}{c}\text { p value } \\
\text { per protocol analysis }\end{array}$ \\
\hline $\begin{array}{c}\text { Duration of diarrhea } \\
\text { Mean (days) } \pm \text { SD }\end{array}$ & $2.45 \pm 1.60$ & $3.47 \pm 2.08$ & 0.018 \\
Mean (hours) \pm SD & $58.74 \pm 38.54$ & $83.37 \pm 49.83$ & \\
Frequency of stools (Mean value \pm SD) & & & \\
Day 0* & $2.79 \pm 0.96$ & $3.05 \pm 0.87$ & 0.215 \\
Day 1 & $1.53 \pm 0.89$ & $1.68 \pm 1.04$ & 0.480 \\
Day 2 & $1.18 \pm 0.61$ & $1.26 \pm 0.86$ & 0.646 \\
Day 3 & $1.03 \pm 0.64$ & $0.97 \pm 0.72$ & 0.736 \\
Day 4 & $1.08 \pm 0.43$ & $1.03 \pm 0.49$ & 0.620 \\
Day 5 & $1.03 \pm 0.54$ & $1.00 \pm 0.61$ & 0.837 \\
Day 6 & $1.00 \pm 0.61$ & $0.95 \pm 0.40$ & 0.659 \\
Day 7 & $1.00 \pm 0.57$ & $0.95 \pm 0.40$ & 0.642 \\
& & & \\
Stool consistency (Mean value \pm SD) & & & \\
Day 0 & $1.50 \pm 0.51$ & $1.68 \pm 0.47$ & 0.105 \\
Day 1 & $0.86 \pm 0.65$ & $1.12 \pm 0.77$ & 0.133 \\
Day 2 & $0.47 \pm 0.56$ & $0.78 \pm 0.71$ & 0.049 \\
Day 3 & $0.37 \pm 0.55$ & $0.37 \pm 0.56$ & 0.953 \\
Day 4 & $0.13 \pm 0.35$ & $0.23 \pm 0.49$ & 0.332 \\
Day 5 & $0.06 \pm 0.23$ & $0.24 \pm 0.50$ & 0.048 \\
Day 6 & $0.03 \pm 0.17$ & $0.15 \pm 0.36$ & 0.083 \\
Day 7 & $0.03 \pm 0.16$ & $0.15 \pm 0.36$ & 0.071 \\
\hline
\end{tabular}

${ }^{*}$ Day 0 corresponds to the first $24 \mathrm{~h}$ period from the initiation of treatment.

Table 3. Improvement of other clinical outcomes of patients receiving Lactobacillus spp. or placebo.

\begin{tabular}{lccccc}
\hline Parameter & \multicolumn{2}{c}{ Lactobacillus spp. (Mean \pm SD) } & \multicolumn{2}{c}{ Placebo (Mean \pm SD) } & \multirow{2}{*}{ p value } \\
\hline Symptoms & Day 0 & Day 7 & Day 0 & Day 7 & \\
\hline Frequency of stools & $2.79 \pm 0.96$ & $1.00 \pm 0.57$ & $3.05 \pm 0.87$ & $0.95 \pm 0.40$ & 1.000 \\
Stool consistency & $1.50 \pm 0.51$ & $0.03 \pm 0.16$ & $1.68 \pm 0.47$ & $0.15 \pm 0.36$ & 0.022 \\
Abdominal pain & $1.53 \pm 0.86$ & $0.13 \pm 0.58$ & $1.82 \pm 1.11$ & $0.13 \pm 0.41$ & 0.820 \\
Nausea & $1.42 \pm 0.95$ & $0.08 \pm 0.36$ & $1.45 \pm 0.95$ & $0.05 \pm 0.23$ & 0.570 \\
Vomiting & $0.82 \pm 1.04$ & $0.03 \pm 0.16$ & $1.26 \pm 1.11$ & $0.03 \pm 0.16$ & 0.921 \\
Bloating & $1.32 \pm 0.87$ & $0.16 \pm 0.55$ & $1.21 \pm 1.07$ & $0.16 \pm 0.55$ & 0.964 \\
Tenesmus & $0.68 \pm 0.87$ & $0.08 \pm 0.36$ & $0.53 \pm 0.95$ & 0.000 & 0.615 \\
Headache & $1.13 \pm 1.04$ & $0.11 \pm 0.39$ & $1.24 \pm 1.02$ & $0.05 \pm 0.23$ & 0.740 \\
Fever (\%) & 52.6 & 5 & 36.8 & 7.9 & 0.276 \\
Thirsty (\%) & 65.8 & 28 & 65.8 & 18.4 & 0.271 \\
\hline
\end{tabular}

other investigators in developing countries (Supcharassaeng and Suankratay, 2011; Wanke, 2011; Okeke et al., 2003). Due to the limited coverage of our study sites, which are the top referral hospitals in our country, it is not possible to extrapolate our findings as a representation of overall condition in the population.

Our study demonstrated that supplementation of combined probiotic product ( $L$. rhamnosus and $L$. acidophilus (Lacidofil@) has shortened the duration of diarrhea $1.02 \pm 0.48$ days sooner than the placebo group. Similar result was also observed in other studies and has been discussed in a meta-analysis on acute diarrhea in children (De Roons and Katan, 2000; Van Niel et al., 2002; Tlaskal et al., 1995, 2005; Reid et al., 2003; Guandalini et al., 2000; Shornikova et al., 1997; Sazawal et al., 2006). Furthermore, several studies have also 
reported that probiotic supplementation of Lactobacillus spp. may accelerate healing process leading to the recovery of acute diarrhea in children and adults (Van Niel et al., 2002; Tiaskal et al., 2005; Guandalini et al., 2000; Shornikova et al., 1997; Canani et al., 2007).

Some investigators found that children with acute gastroenteritis treated orally with the probiotic combination of $L$. acidophilus and $L$. rhamnosus experienced significantly faster improvement of stool consistency compared to the control group $(p<0.003)$. They demonstrated that improved stool consistency was observed in $4 \pm 2.02 \mathrm{~h}$ for children treated orally with probiotic products and the improvement was observed in $5.45 \pm 2.33 \mathrm{~h}$ for those without probiotic treatment (Tlaskal et al., 2005).

Several studies have indicated that Lactobacilli may bring remarkable recovery of acute diarrhea and improved clinical outcomes as a result from some mechanisms, such as by (1) binding the intestinal mucosa receptors and preventing pathogen adhesion and invasion to the intestinal epithelium; (2) stimulating immune response and also (3) producing protective immunomodulatory effects by increasing $\lg \mathrm{A}$ secretion (Tlaskal et al., 2005; Reid et al., 2003). Moreover, a systematic review and meta-analysis suggests that probiotics are associated with a reduction in antibioticassociated diarrhea (Hempel et al., 2012).

In another study, however, the beneficial effect of probiotic supplementation on the recovery of acute diarrhea were not observed compared to placebo (Ritchie et al., 2010). Greater improvement on clinical outcomes (frequency of stools, stool consistency, abdominal pain, nausea, vomiting, bloating, headache, fever and tenesmus) were observed in the group receiving Lactobacillus spp. supplementation; however, the result was statistically significant on stool consistency only. Similar results were found in other studies (De Roons and Katan, 2000; Van Niel et al., 2002; Tlaskal et al., 1995, 2005; Reid et al., 2003; Guandalini et al., 2000; Shornikova et al., 1997).

In contrast, significant improvements were observed in children with gastrointestinal disease treated with probiotic supplementation including stomach pain, vomiting, fever and loss of appetite. Children who received probiotic supplementation of $L$. acidophilus had significant faster recovery than those without the probiotic (Tlaskal et al., 1995, 2005). No serious adverse event was found in our study, since acute diarrhea is usually mild and self-limiting. Moreover, placebo treatment may bring therapeutic-like effect in 40 to $50 \%$ cases. Other randomized-control trials (RCTs) have also shown similar results (Guandalini, 2012; Hatchette and Farina, 2011; Patro et al., 2010).

The limitation of our study includes inadequate laboratory examination such as stool culture and viral test to reveal the infectious causative agents of acute diarrhea, which could not be performed due to limited budget and facilities; therefore, infections was defined based on history, physical examination and positive laboratory test results of blood test and routine stool analysis.

\section{Conclusion}

Our study has demonstrated the beneficial effect of combined probiotic supplementation of L. rhamnosus and $L$. acidophilus on improving the clinical outcomes of acute diarrhea and shortening the duration of diarrhea in adult patients. The results are consistent with the well-known, reproducible capability of Lactobacillus spp. to shorten the duration of diarrhea by approximately 1 day.

Combined probiotic supplementation appears to be a promising therapeutic agent for treatment of acute diarrhea in adults. However, there is concern that although probiotics are considered nonpathogenic, it may be infective when the patient is severely ill or immunosuppressed. Moreover, some factors should be considered, including the safety, strain selection, product stability and formulation. It should always be kept in mind that probiotic must stay viable to bring the beneficial effect and its viability is affected by temperature, humidity and oxygen concentration. The product should also be delivered in right dose. Lower dose of probiotic in the market may not provide the beneficial effects as reported in clinical studies. Therefore, further controlled clinical studies, as well as good storage, handling and distribution is essential to explore the therapeutic benefit for possible practical clinical application.

\section{ACKNOWLEDGEMENTS}

The authors thank Aan Santi, Indri Rizkiany for their help and assistance in this study. This study was financially supported by Dexa Medica Ltd and Rossel Institute.

\section{REFERENCES}

Agustina R, Lukito W, Firmansyah A, Suhardjo HN, Murniati D, Bindels J (2007). The effect of early nutritional supplementation with a mixture of probiotic, prebiotic, fiber and micronutrients in infants with acute diarrhea in Indonesia. Asia Pac. J. Clin. Nutr. 16:435-442.

Canani RB, Cirillo P, Terrin G, Cesarano L, Spagnuolo MI, De Vincenzo A Albano F, Passariello A, De Marco M, Manguso F, Guarino A (2007). Probiotics for treatment of acute diarrhoea in children: Randomised clinical trial of five different preparations. BMJ 335:340.

De Roons NM, Katan MB (2000). Effects of Probiotic Bacteria on Diarrhea, lipid metabolism, and carcinogenesis: A review of papers published between 1988 and 1998. Am. J. Clin. Nutr. 71:405-411.

Field M (2003). Intestinal ion transport and the pathophysiology of diarrhea. J. Clin. Investig. 111:931-943.

Guandalini S, Pensabene L, Zikri MA, Dias JA, Casali LG, Hoekstra H Kolacek S, Massar K, Micetic-Turk D, Papadopoulou A, de Sousa JS, Sandhu B, Szajewska H, Weizman Z (2000). Lactobacillus GG administered in oral rehydration solution to children with acute diarrhea: A multicenter European trial. J. Pediatr. Gastroenterol. Nutr. 30:54-60.

Guandalini S (2012). Diarrhea. Accessed 21 April 2012. Available from url: http://emedicine.medscape.com/article/928598-overview. 
Guerrant RL, Van Gilder T, Steiner TS, Thielman NM, Slutsker L, Tauxe RV, Hennessy T, Griffin PM, DuPont H, Sack RB, Tarr P, Neill M, Nachamkin I, Reller LB, Osterholm MT, Bennish ML, Pickering LK (2001). Practice guidelines for the management of infectious diarrhea. Clin. Infect. Dis. 32:331-351.

Hatchette TF, Farina D (2011). Infectious diarrhea: When to test and when to treat. CMAJ 183:339-344.

Hatta M, Supriatmo AM, Sinuhaji AB, Hasibuan B, Nasution FL (2011). Comparison of zinc-probiotic combination theraphy to zinc theraphy alone in reducing the severity of acute diarrhea. Paediatr. Indones 51:1-6.

Hempel S, Newbery SJ, Maher AR, Wang Z, Miles JN, Shanman R, Johnsen B, Shekelle PG (2012). Probiotics for the prevention and treatment of antibiotic-associated diarrhea: A systematic review and meta-analysis. JAMA 307(18):1959-1969.

Hendarwanto (1996). Diare akut Karena Infeksi. In: Waspadji S, Rachman AM, Lesmana LA, et.al. editors. Buku Ajar IImu Penyakit Dalam Jilid I. $3^{\text {rd }}$ edition. Jakarta: Pusat Informasi dan Penerbit Bagian IImu Penyakit Dalam FKUI pp. 451-457.

Manatsathit S, Dupont HL, Farthing M, Kositchaiwat C, Leelakusolvong S, Ramakrishna BS, Sabra A, Speelman P, Surangsrirat S (2002). Guideline for the management of acute diarrhea in adults. J. Gastroenterol. Hepatol. 17(Suppl):S54-S71.

Okeke IN, Ojo O, Lamikanra A, Kaper JB (2003). Etiology of Acute Diarrhea in Adults in Southwestern Nigeria. J. Clin. Microbiol. 41:4525-4530.

Oyofo BA, Lesmana M, Subekti D, Tjaniadi P, Larasati W, Putriad M Putri M, Simanjuntak $\mathrm{CH}$, Punjabi NH, Santoso W, Sriwati MS, Sarumpaet S, Abdi M, Tjindi R, Ma'ani $H$, Sumardiati A, Handayani H, Campbell JR, Alexander WK, Beecham HJ, Corwin AL (2002). Surveillance of bacterial pathogens of diarrhea disease in Indonesia. Diagn. Microb. Infect. Dis. 44:227-234.

Patro B, Szymański H, Szajewska H (2010). Oral zinc for the treatment of acute gastroenteritis in Polish children: A randomized, doubleblind, placebo-controlled trial. J. Pediatr. 157:984-988.e1.

Putra IGN, Suraatmaja S, Aryasa IKN (2007). Effects of probotics supplementation for infants with acute diarrhea: A randomized double blind clinical trial. Paediatr. Indones. 47:172-178.

Qadri F, Svennerholm AM, Faruque ASG, Sack RB (2005). Enterotoxigenic Escherichia coli in Developing Countries: Epidemiology, Microbiology, Clinical Features, Treatment, and Prevention. Clin. Microb. Rev. 18:465-483.

Rani HAA (2002). Masalah Dalam Penatalaksanaan Diare Akut pada Orang Dewasa.In: Setiati S, Alwi I, Kasjmir YI, dkk, Editors. Current Diagnosis and Treatment in Internal Medicine 2002. Jakarta: Pusat Informasi Penerbitan Bagian Penyakit Dalam FK UI pp. 49-56.

Reid G, Jass J, Sebulsky MT, McCormick JK (2003). Potential uses of probiotics in clinical practice. Clin. Microb. Rev. 16:658-672.

Ritchie BK, Brewster DR, Tran CD, Davidson GP, McNeil Y, Butler RN (2010). Efficacy of Lactobacillus GG in aboriginal children with acute diarrhoeal disease: A randomised clinical trial. J. Pediatr. Gastroenterol. Nutr. 50:619-624.
Sazawal S, Hiremath G, Dhingra U, Malik P, Deb S, Black RE (2006). Efficacy of probiotics in prevention of acute diarrhoea: $A$ metaanalysis of masked, randomised, placebo-controlled trials. Lancet Infect. Dis. 6:374-382.

Shornikova AV, Casas IA, Mykkanen H, Salo E, Vesikari T(1997). Bacteriotherapy with Lactobacillus reuteri in rotavirus gastroenteritis. Pediatr. Infect. Dis. J. 16:1103-1107.

Supcharassaeng S, suankratay C (2011). Antibiotic prescription for adults with acute diarrhea at King Chulalongkorn Memorial Hospital Thailand. J. Med. Assoc. Thai. 94:545-550.

The World Bank-Agriculture and Rural Development (2012). Poor Sanitation Still Causes Heavy Health and Economic Losses in Indonesia. Accessed 20 April 2012. Available from url:http://web.worldbank.org/WBSITE/EXTERNAL/TOPICS/EXTARD/ 0,,contentMDK:21875467 menuPK:336719 pagePK:64020865 piP K:149114 theSitePK:336682,00.html.

Tlaskal P, Michkova E, Klayarova H, Jerabkova L, Nevoral J, Balackova J, Tejnecka J, Valtrova V, Simandlova M, Kejvalova L (1995). Lactobacillus Acidophilus in the treatment of children with gastrointestinal tract illnesses. Cesko-Slovenska Pediatric 1995 and Nutrition, Aliments Fonctionnels, Aliments Santé 2005. CeskoSlovenska Pediatr. 51:615-619.

Tlaskal P, Schramlova J, Kokesova A, Adamus J, Bubakova D, Kocnarova N, Kopecka K, Muckovn J, Pacovska E, Sladkova E (2005). Probiotics in the treatment of diarrhoeal disease in children. Cesko-Slovenska Pediatric 1995 and Nutrition, Aliments Fonctionnels, Aliments Santé 2005. NAFAS. 3:25-28.

Unicef Indonesia (2012). Overview - Water \& Environmental Sanitation. $\begin{array}{lllll}\text { Accessed } 20 & \text { April } 2012 . & \text { Available from }\end{array}$ url:http://www.unicef.org/indonesia/wes.html.

USAID Indonesia (2012). USAID Indonesia Urban Water, Sanitation, and Hygiene Project (USAID IUWASH). Accessed 21 April 2012. Available from url: http://indonesia.usaid.gov/en/USAID/Activity/269/USAID Indonesia Urban_Water_Sanitation_and_Hygiene_Project_USAID_IUWASH.

Van Niel CW, Feudtner C, Garrison MM, Christakis DA (2002). Lactobacillus therapy for acute infectious diarrhea in children: A meta-analysis. Pediatrics 109:678-684.

Wanke CA (2011). Approach to the adult with acute diarrhea in developed countries. Accessed 29 August 2011. Available from url:http://www.uptodate.com/contents/approach-to-the-adult-withacute-diarrhea-in-developed-countries.

World Gastroenterology Organisation (2008). Practice guideline: Acute diarrhea. Accessed 29 August 2011. Available from Url:http://www.omge.org/assets/downloads/en/pdf/guidelines/01_acut e_diarrhea.pdf. 